\title{
MiR-2964a-5p binding site SNP regulates ATM expression contributing to age-related cataract risk
}

\author{
Han Rong ${ }^{1,2}$, Shanshan $\mathbf{G u}^{1}$, Guowei Zhang ${ }^{1}$, Lihua Kang ${ }^{1}$, Mei Yang ${ }^{1}$, Junfang \\ Zhang ${ }^{1}$, Xinyue Shen ${ }^{1}$ and Huaijin Guan ${ }^{1}$ \\ ${ }^{1}$ Eye Institute, Affiliated Hospital of Nantong University, Nantong, Jiangsu, China \\ ${ }^{2}$ Eye Department, The Affiliated Huai'an Hospital of Xuzhou Medical University and The Second People's Hospital of Huai'an, \\ Huai'an, Jiangsu, China \\ Correspondence to: Huaijin Guan, email: guanhjeye@163.com \\ Keywords: microRNA, DNA damage, single-nucleotide polymorphisms (SNPs), ataxia telangiectasia mutated (ATM) gene, age- \\ related cataract \\ Received: December 05, $2016 \quad$ Accepted: April 11, $2017 \quad$ Published: May 03, 2017 \\ Copyright: Rong et al. This is an open-access article distributed under the terms of the Creative Commons Attribution License 3.0 (CC BY 3.0), \\ which permits unrestricted use, distribution, and reproduction in any medium, provided the original author and source are credited.
}

\section{ABSTRACT}

This study was to explore the involvement of DNA repair genes in the pathogenesis of age-related cataract (ARC). We genotyped nine single nucleotide polymorphisms (SNPs) of genes responsible to DNA double strand breaks (DSBs) in 804 ARC cases and 804 controls in a cohort of eye diseases in Chinese population and found that the ataxia telangiectasia mutated (ATM) gene-rs4585:G >T was significantly associated with ARC risk. An in vitro functional test found that miR-2964a-5p specifically down-regulated luciferase reporter expression and ATM expression in the cell lines transfected with rs4585 $\mathrm{T}$ allele compared to rs4585 $\mathrm{G}$ allele. The molecular assay on human tissue samples discovered that ATM expression was down-regulated in majority of ARC tissues and correlated with ATM genotypes. In addition, the Comet assay of cellular DNA damage of peripheral lymphocytes indicated that individuals carrying the G allele (GG/GT) of ATM-rs4585 had lower DNA breaks compared to individuals with TT genotype. These findings suggested that the SNP rs4585 in ATM might affect ARC risk through modulating the regulatory affinity of miR-2964a-5p. The reduced DSBs repair might be involved in ARC pathogenesis.

\section{INTRODUCTION}

Age-related cataract (ARC) is a progressive opacification of the ocular lens which can lead to visual impairment and blindness. Based on the opacity location within the lens, ARC can be classified into the following subtypes: cortical cataract $(\mathrm{C})$, nuclear cataract $(\mathrm{N})$, posterior subcapsular cataract (PSC) and mixed cataract (M)[1]. ARC is a multifactorial disease caused by the interactions between genes and environmental factors. Until now, various risk factors like aging, diabetes, gender, sunlight radiation and UV exposure have been associated with cataract development and progression [2].

Currently, the biological processes of ARC are still not fully understood. It is known that external factors such as ionizing radiation and certain chemotherapeutic drugs can generate oxidative stress and induce damages of DNA within the lens epithelium. Disrupted DNA repair genes, which could be caused by gene variation, have been reported to be strongly associated with ARC $[3,4]$.

Within the mammalian cells, the most severe recorded form of DNA damage is the double-strand DNA breaks (DSB), which usually triggers an irreversible DNA damage response and consequently cell death [5]. It is known that the mechanism of DSB repair (DSBr) includes two distinct pathways: homologous recombination (HR) and non-homologous end joining [6, 7]. HR is partially promoted by the ataxia telangiectasia (ATM) gene. The loss of $A T M$ gene may lead to low efficiency of HR-mediated $\mathrm{DSBr}$ within the cell $[8,9]$. Briefly, immediately after the cells have been exposed to radiation, reactive oxidative stress is produced and causes DNA damage. This results in rapid recruitment of repair signal and proteins, as well as an alteration of chromatin structure [10]. When DNA breakage occurs, $A T M$ is recruited to the lesion site, thus promoting DSBr and amplifying other DSB signals [11]. 
Because of ATM's central role in DSBr [12], it is plausible that disrupted $A T M$ function might be associated with the occurrence of ARC. Several studies have suggested that specific single-nucleotide polymorphisms (SNPs) within the genes of DSBr pathway may be associated with ARC risk, which include PARP-1 [13], ZNF350 [14], XRCC 1[15], WRN [16] and EPHA2 [17].

MicroRNAs (miRNAs) are a class of small noncoding RNAs containing approximately 22 nucleotides, which bind to the 3'-untranslated region (3'-UTR) of multiple target mRNAs and block the target translation or initiate a target degradation [18-20]. SNPs present in miRNA-target sites (miRSNPs), and in the 3'UTR of genes, represent a specific class of functional polymorphisms and may lead to the dysregulation of posttranscriptional gene expression by disrupting regulatory miRNA binding [21]. It has been documented that SNPs in miRNA-target sites confer risky predisposition to complex human diseases, including hypertension [22], cancer [23], Tourette syndrome [24], asthma [25], and Parkinson disease [26].

Recently we have reported several ARC associated SNPs located in intron and coding regions in DNA repair genes such as $W R N$ and $B L M$ [3]. In this paper, we described a case-control study that aimed to test the relationship between ARC and miRSNPs in the 3'-UTR sequence of $A T M$ gene along with its downstream genes FANCD2 [27], BRIP1 [28], TP53 [29], EPHA2 [30] and NEIL2 [31]. Subsequently, in vitro and in vivo assays were conducted in order to clarify the function of the associated SNP.

\section{RESULTS}

The study population was recruited from the epidemiologic survey that comprised 804 patients with ARC and 804 age-, sex- and ethnically-matched healthy control subjects. The general demographic details of the study participants were summarized in Table 1. No statistically significant difference with regard to age and gender was found between case and control populations $(P>0.05)$. Nine SNPs in 3'-UTR region of 7 genes were selected for genotyping, and their basic characteristics and predicted miRNAs binding sites were listed in Table 2. All of the tested SNPs are in HWE in the control population, except EPHA2 rs1803527 $(P<0.05)$ that was excluded from further analysis. We compared the allele frequency between ARC patients and normal controls and found that only $A T M$-rs4585 was associated with ARC $(P=0.0022, \mathrm{OR}=1.24,95 \% \mathrm{CI}: 1.06-1.40$; Table 3$)$, and the significance remained after Bonferroni correction $(\mathrm{Pa}=0.0198)$.

We then analyzed the distribution of allele frequencies after stratifying $\mathrm{ARC}$ by the subtypes. Briefly, ATM-rs4585 was also found to be associated with the cortical and mixed types of ARC $(P=0.02, \mathrm{OR}=1.25$,
Table $5 ; P=0.009, \mathrm{OR}=1.40$, Table 4 ), suggesting a risk role for the minor " $\mathrm{T}$ " allele in development of the cortical and mixed types of ARC. In addition, ATMrs4585 was marginally associated with the nuclear cataract $(P=0.03, \mathrm{OR}=1.22$; Table 4$)$. FANCD2rs7647987 was suggestively associated with the nuclear cataract $(P=0.046, \mathrm{OR}=0.75,95 \% \mathrm{CI}$ : 0.56-0.99; Table 5 ). From the genetic model analysis, we found that the association of rs4585 with ARC and various subtypes were largely in the recessive model (Table 4), while the association of rs 7647987 with nuclear cataract was in the dominant model (Table 5). However, all the associations in genetic model analysis lost significance after using the Bonferroni correction method. This could be explained by the smaller sample size in counting individuals compared to alleles $(P>0.05$; Tables 4,5$)$. Furthermore, the subtype analysis showed that other SNPs were not associated with ARC subtypes.

Using the miRNA-target prediction tools, we determined that the ATM 3'-UTR harbored a putative miR2964a-5p miRNA binding site (Figure 1A). In accordance with the previous predictions, the relative luciferase activity was lower in the presence of the " $T$ " than of the "G" allele in both HepG2 $(P<0.01)$ and HEK293T $(P<0.01)$ cells, and without an addition of external miRNA (Figure 1B). Moreover, synthesized miR-2964a-5p mimics significantly down-regulated luciferase reporter expression in both cell lines transfected with rs 4585 " $\mathrm{T}$ " allelic reporter constructs compared to miRNA-control (miR-con), whereas there was no such suppression of luciferase activities in both cell lines transfected with the "G" allelic reporter constructs by the miRNA mimics (Figure 1B). Notably, the reporter expression was lower in the presence of the "T" than of the " $G$ " allele, which might be explained by the existence of endogenously miRNAs. In addition, co-transfection with miR-2964a-5p inhibitors, chemically synthesized oligonucleotides that neutralize endogenous miRNA, significantly recovered the activities of reporter gene with the rs4585 " $\mathrm{T}$ " allele (Figure 1C), while no change was observed for reporter gene expression with the " $G$ " allele treated with the inhibitors (data not shown).

Considering the direct association found between miR-2964a-5p and ATM 3'-UTR (results found by using luciferase assay), we further investigated whether miR2964a-5p alone could inhibit ATM expression in cell lines carrying the TT genotype. We measured ATM expression directly, after transfecting HEK293T cells (TT genotype) with miR-2964a-5p mimics and miR-2964a-5p inhibitors. As shown in Figure 2A, the ATM expression decreased when mimics were added, while the suppression of ATM expression was abolished as the inhibitors were cotransfected. Furthermore, we validated if miR-2964a-5p can down-regulate the expression of ATM in LEC lines, miR-2964a-5p mimics or inhibitors were transfected into HLEPIC-LECs (TT genotype), similar results were observed change (Figure 2B, 2C, 2D). 
Table 1: Demographic Information of Study Participants

\begin{tabular}{|c|c|c|c|}
\hline Variable & Control & ARC & $P$ \\
\hline$n$ & 804 & 804 & NA \\
\hline $\begin{array}{l}\text { Fasting blood sugar, } \\
\text { mean } \pm \mathrm{SD}\end{array}$ & $69.66 \pm 4.51$ & $70.38 \pm 7.72$ & 0.735 \\
\hline Age, $y$, mean \pm SD & $70.39 \pm 5.42$ & $70.87 \pm 7.23$ & 0.132 \\
\hline Female, n (\%) & $455(56.6)$ & $490(60.9)$ & 0.076 \\
\hline Male, n (\%) & $349(43.4)$ & $314(39.1)$ & \\
\hline $\mathrm{C}, \mathrm{n}(\%)$ & 0 & $284(35.32)$ & NA \\
\hline $\mathrm{N}, \mathrm{n}(\%)$ & 0 & $349(43.41)$ & NA \\
\hline PSC, n (\%) & 0 & $33(4.11)$ & NA \\
\hline $\mathrm{M}, \mathrm{n}(\%)$ & 0 & $138(17.16)$ & NA \\
\hline
\end{tabular}

Abbreviations: C, cortical; N: nuclear; P, posterior subcapsular cataract; $\mathrm{M}$, mixed type

Table 2: The Tested 9 SNPs within The 3'-UTR of the Selected 7 Genes in DSBR

\begin{tabular}{|c|c|c|c|c|c|}
\hline Gene Name & SNPs & Assay ID & $\begin{array}{c}\text { Nucleotide } \\
\text { change }\end{array}$ & $\mathbf{M A F}^{*}$ & miRNA binding \\
\hline ATM & rs4585 & C__1039793_20 & $\mathrm{G}>\mathrm{T}$ & 0.42 & hsa-miR-2964a-5p \\
\hline \multirow[t]{2}{*}{ FANCD2 } & rs7647987 & C_189399221_10 & $\mathrm{A}>\mathrm{G}$ & 0.15 & hsa-miR-4765 \\
\hline & rs3172417 & C__27465020_10 & $\mathrm{C}>\mathrm{T}$ & 0.10 & hsa-miR-516b-5p \\
\hline \multirow[t]{2}{*}{$B R I P 1$} & rs7213430 & C_ $2547428 \_10$ & $\mathrm{~A}>\mathrm{G}$ & 0.33 & hsa-miR-4645-3p \\
\hline & rs11079454 & C__341518_20 & $\mathrm{T}>\mathrm{A}$ & 0.44 & $\begin{array}{l}\text { hsa-miR-101-5p } \\
\text { hsa-miR-559 } \\
\text { hsa-miR-548b-5p }\end{array}$ \\
\hline TP53 & rs 1042522 & C__2403545_10 & $\mathrm{C}>\mathrm{G}$ & 0.42 & hsa-miR-399a-3p \\
\hline EPHA2 & rs 1803527 & C__1472045_20 & $\mathrm{A}>\mathrm{G}$ & 0.11 & hsa-miR-337-3p \\
\hline NEIL 2 & rs1534862 & C_ $2716225 \_10$ & $\mathrm{C}>\mathrm{T}$ & 0.24 & $\begin{array}{l}\text { hsa-miR-4289 } \\
\text { hsa-miR-544a }\end{array}$ \\
\hline PARP-1 & rs8679 & $9632806 \quad 10$ & $\mathrm{~T}>\mathrm{C}$ & 0.07 & hsa-miR-4255 \\
\hline
\end{tabular}

*MAF, minor allele frequency in Chinese population.

In addition, we measured the $A T M$ expression levels within LECs. The ATM mRNA expression was lower in the ARC group compared to the Control group regardless of genotypes (Figure $3 \mathrm{~A}$ ), significant mRNA expression was observed in the cortical, posterior subcapsular and mixed types of ARC (Figure 3B). Moreover, a number of anterior capsule samples, with different genotypes of rs4585, proved that real biological effects resulted from the allele difference. The results from ARC individuals showed that "TT" genotype of rs4585 $(\mathrm{n}=11)$ has lower level of ATM mRNA (Figure 3D) and protein expression (Figure 3E, F) compared to other two genotypes ( "TT" versus "GG", $P<0.01$; “TT" versus "GT", $P<$
0.01; Figure 3D), although no significant differences were found between "GG" $(\mathrm{n}=14)$ and "GT" $(\mathrm{n}=17)$ genotypes ( "GG" versus "GT", $P>0.05$ ). In order to further investigate the possible regulation of $A T M$ mRNA by miR-2964a-5p, and the expression in a genotype-dependent manner, 30 tissue samples were used to detect the expression level of miR-2964a-5p. However, miR-2964a-5p expression was not influenced by $A T M$ genotype (Figure $3 \mathrm{C}$ ). Thus, by conclusion, our results surrested that variant alleles in the ATM 3'-UTR affect the binding ability of miR-2964a-5p to ATM, but not the abundance of miR-2964a-5p itself.

The peripheral lymphocytes DNA breaks analysis showed that the percentage of DNA in the tail of Comets 
Table 3: Distribution of Minor Allele of Tested 9 SNPs and Their Association with ARC

\begin{tabular}{|c|c|c|c|c|c|c|}
\hline Gene & $\begin{array}{c}\text { SNPs } \\
\text { Minor/Major }\end{array}$ & $\begin{array}{c}\text { Control } \\
\text { Minor/ } \\
\text { Major(\%) }\end{array}$ & $\begin{array}{c}\text { All ARC } \\
\text { Minor/ } \\
\text { Major(\%) }\end{array}$ & $\chi^{2}$ & $P$ & $\begin{array}{c}\text { OR } \\
(95 \% \mathrm{CI})\end{array}$ \\
\hline ATM & $\begin{array}{c}\mathrm{rs} 4585 \\
\mathrm{~T} / \mathrm{G}\end{array}$ & $\begin{array}{c}658 / 950 \\
(40.92)\end{array}$ & $\begin{array}{c}744 / 864 \\
(46.27)\end{array}$ & 9.35 & $\begin{array}{c}0.0022 / \\
0.0198(\mathrm{~Pa})\end{array}$ & $\begin{array}{c}1.24 \\
(1.06-1.40)\end{array}$ \\
\hline \multirow[t]{2}{*}{$F A N C D 2$} & $\begin{array}{c}\mathrm{rs} 3172417 \\
\mathrm{~T} / \mathrm{C}\end{array}$ & $\begin{array}{c}199 / 1409 \\
(12.38)\end{array}$ & $\begin{array}{c}206 / 1402 \\
(12.81)\end{array}$ & 0.14 & 0.71 & $\begin{array}{c}1.04 \\
(0.84-1.28)\end{array}$ \\
\hline & $\begin{array}{c}\text { rs } 7647987 \\
\mathrm{G} / \mathrm{A}\end{array}$ & $\begin{array}{c}206 / 1402 \\
(12.81)\end{array}$ & $\begin{array}{c}192 / 1416 \\
(11.94)\end{array}$ & 0.56 & 0.45 & $\begin{array}{c}0.92 \\
(0.75-1.14)\end{array}$ \\
\hline \multirow[t]{2}{*}{ BRIP1 } & $\begin{array}{c}\text { rs } 7213430 \\
\text { G/A }\end{array}$ & $\begin{array}{c}419 / 1189 \\
(26.06)\end{array}$ & $\begin{array}{c}416 / 1192 \\
(25.87)\end{array}$ & 0.01 & 0.90 & $\begin{array}{c}0.99 \\
(0.84-1.16)\end{array}$ \\
\hline & $\begin{array}{c}\text { rs } 11079454 \\
\mathrm{~A} / \mathrm{T}\end{array}$ & $\begin{array}{c}797 / 811 \\
(49.56)\end{array}$ & $\begin{array}{c}778 / 830 \\
(48.38)\end{array}$ & 0.45 & 0.50 & $\begin{array}{c}0.93 \\
(0.83-1.10)\end{array}$ \\
\hline TP53 & $\begin{array}{c}\text { rs } 1042522 \\
\text { G/C }\end{array}$ & $\begin{array}{c}690 / 918 \\
(42.91)\end{array}$ & $\begin{array}{c}684 / 924 \\
(42.54)\end{array}$ & 0.05 & 0.83 & $\begin{array}{c}0.98 \\
(0.86-1.13)\end{array}$ \\
\hline EPHA2 & $\begin{array}{c}\text { rs } 1803527 \\
\text { G/A }\end{array}$ & $\begin{array}{c}193 / 1415 \\
(12)\end{array}$ & $\begin{array}{c}181 / 1427 \\
(11.26)\end{array}$ & 0.44 & 0.51 & $\begin{array}{c}0.93 \\
(0.75-1.15)\end{array}$ \\
\hline NEIL2 & $\begin{array}{c}\mathrm{rs} 1534862 \\
\mathrm{~T} / \mathrm{C}\end{array}$ & $\begin{array}{c}385 / 1223 \\
(23.94)\end{array}$ & $\begin{array}{c}373 / 1235 \\
(23.2)\end{array}$ & 0.25 & 0.62 & $\begin{array}{c}0.9594 \\
(0.82-1.13)\end{array}$ \\
\hline$P A R P-1$ & $\begin{array}{c}\mathrm{rs} 8679 \\
\mathrm{C} / \mathrm{T}\end{array}$ & $\begin{array}{c}100 / 1508 \\
(6.22)\end{array}$ & $\begin{array}{c}82 / 1526 \\
(5.1)\end{array}$ & 1.88 & 0.17 & $\begin{array}{c}0.81 \\
(0.60-1.09)\end{array}$ \\
\hline
\end{tabular}

All HWE $(P>0.05)$ except EPHA2-rs1803527 $(P<0.05)$. Pa, $P$ value after Bonferroni correction.

Table 4: Association between $A T M-r s 4585$ and ARC

\begin{tabular}{|c|c|c|}
\hline Allele & G/T & GG+TG/TT \\
\hline Control, n (\%) & $950(59.08) / 658(40.92)$ & $664(82.59) / 140(17.41)$ \\
\hline General ARC, n (\%) & $864(53.73) / 744(46.27)$ & $621(77.24) / 183(22.76)$ \\
\hline $\begin{array}{l}\mathrm{P} / \mathrm{Pa} \\
\mathrm{OR}(95 \% \mathrm{CI})\end{array}$ & $\begin{array}{c}\mathbf{0 . 0 0 2 2} / \mathbf{0 . 0 1 9 8} \\
1.24(1.06-1.40)\end{array}$ & $\begin{array}{c}0.07 / 0.63 \\
1.40(1.09-1.79)\end{array}$ \\
\hline Cortical cataract, $\mathrm{n}(\%)$ & $304(53.52) / 264(46.48)$ & $211(77.01) / 63(22.99)$ \\
\hline $\begin{array}{l}\mathrm{P} / \mathrm{Pa} \\
\mathrm{OR}(95 \% \mathrm{CI})\end{array}$ & $\begin{array}{c}\mathbf{0 . 0 2} / 0.18 \\
1.25(1.03-1.52)\end{array}$ & $\begin{array}{c}\mathbf{0 . 0 4 9} / 0.45 \\
1.35(1.00-1.88)\end{array}$ \\
\hline Nuclear cataract, $\mathrm{n}(\%)$ & $379(54.3) / 319(45.7)$ & $269(77.08) / 80(22.92)$ \\
\hline $\begin{array}{l}\mathrm{P} / \mathrm{Pa} \\
\mathrm{OR}(95 \% \mathrm{CI})\end{array}$ & $\begin{array}{c}\mathbf{0 . 0 3} / 0.27 \\
1.22(1.02-1.45)\end{array}$ & $\begin{array}{c}\mathbf{0 . 0 3} / 0.27 \\
1.41(1.04-1.92)\end{array}$ \\
\hline Posterior subcapsular cataract, n (\%) & $41(62.1) / 25(37.9)$ & $39(90.70) / 4(9.30)$ \\
\hline $\begin{array}{l}P / \mathrm{Pa} \\
\mathrm{OR}(95 \% \mathrm{CI})\end{array}$ & $\begin{array}{c}0.62 / 5.58 \\
0.88(0.53-1.46)\end{array}$ & $\begin{array}{c}0.21 / 1.89 \\
0.65(0.23-1.89)\end{array}$ \\
\hline Mixed type of cataract, n (\%) & $140(50.72) / 136(49.28)$ & $102(73.91) / 36(26.09)$ \\
\hline $\begin{array}{l}P / \mathrm{Pa} \\
\mathrm{OR}(95 \% \mathrm{CI})\end{array}$ & $\begin{array}{c}\mathbf{0 . 0 0 9} / 0.081 \\
1.40(1.09-1.81)\end{array}$ & $\begin{array}{c}\mathbf{0 . 0 2} / 0.18 \\
1.67(1.10-1.55)\end{array}$ \\
\hline
\end{tabular}


Table 5: Association between FANCD2-rs7647987 and ARC

\begin{tabular}{|c|c|c|}
\hline Allele & G/A & $\mathbf{G G} / \mathbf{A G}+\mathbf{A A}$ \\
\hline Control, n (\%) & $1402(87.19) / 206(12.81)$ & $610(75.87) / 194(24.13)$ \\
\hline General ARC, n (\%) & $1416(88.06) / 192(11.94)$ & $628(78.11) / 176(21.89)$ \\
\hline$P / \mathrm{Pa}$ & $0.45 / 4.05$ & $0.29 / 2.61$ \\
\hline OR $(95 \% \mathrm{CI})$ & $0.92(0.75-1.14)$ & $0.88(0.70-1.11)$ \\
\hline cortical cataract, n (\%) & $450(79.23) / 118(20.77)$ & $219(77.11) / 65(22.89)$ \\
\hline$P / \mathrm{Pa}$ & $0.12 / 1.08$ & $0.67 / 6.03$ \\
\hline OR $(95 \% \mathrm{CI})$ & $0.83(0.66-1.05)$ & $0.93(0.68-1.29)$ \\
\hline Nuclear cataract, n (\%) & $629(90.11) / 69(9.89)$ & $284(81.38) / 65(18.62)$ \\
\hline$P / \mathrm{Pa}$ & $\mathbf{0 . 0 4 6} / 0.45$ & $\mathbf{0 . 0 4} / 0.36$ \\
\hline OR $(95 \% \mathrm{CI})$ & $0.75(0.56-0.99)$ & $0.72(0.53-0.99)$ \\
\hline Posterior subcapsular cataract, n (\%) & $53(80.30) / 13(19.70)$ & $23(69.7) / 10(30.3)$ \\
\hline$P / \mathrm{Pa}$ & $0.10 / 0.90$ & $0.42 / 3.78$ \\
\hline OR $(95 \% \mathrm{CI})$ & $1.67(0.89-3.12)$ & $1.37(0.64-2.92)$ \\
\hline Mixed type of cataract, n (\%) & $237(85.87) / 39(14.13)$ & $102(73.91) / 36(26.09)$ \\
\hline$P / \mathrm{Pa}$ & $0.55 / 4.95$ & $0.62 / 5.58$ \\
\hline OR $(95 \% \mathrm{CI})$ & $1.12(0.77-1.62)$ & $1.11(0.73-1.68)$ \\
\hline
\end{tabular}

(the tail DNA\%) and the value of the Olive Tail Moment (OTM) were significantly different in ARC group (Figure 4A) or all ARC subtypes group (Figure 4B) compared to the non-ARC controls $(P<0.001)$. We also found that there was a good correlation of DNA breaks with the rs4585 genotypes. Homozygous "T" allele carriers of ATM-rs4585 had more DNA breaks compared to "G" allele carriers in ARC, cortical, posterior subcapsular and mixed cataract patients $(P<0.05$; Figure $4 \mathrm{~A}$ and $\mathrm{B})$. We also stratified the results by males and females and did not find the difference in the DNA breaks between the genders $(P>0.05$, data not shown).

\section{DISCUSSION}

DNA damage is considered to be a crucial contributor to the formation of $\mathrm{ARC}$, and its timely repair is essential for maintaining the lens' transparency [32]. ATM gene has been shown to play an important role in DNA repair. Previous studies have reported correlations between DNA repair capacity and the regulation of ATM expression $[33,34]$. It has been demonstrated that the aberrant overexpression of miR-421 may down-regulated $A T M$, therefore, can lead to SKX squamous cell carcinoma [35].In addition, it has been shown that miR-203 may be responsible for $A T M$ down-regulation in breast cancers [12].

In this case-control study, we found that only rs4585 in ATM was solidly associated with an increased risk of ARC. Furthermore, we have characterized rs4585 as a unique SNP that conferred a genetic effect on gene regulation by miRNA binding. MiRNAs are short genetic sequences with the ability to regulate gene expression by binding to the 3'-UTR of the target gene [36]. Different expression profiles of miRNAs were identified in the central epithelium of transparent and cataractous human lenses [37]. Our results have suggested that miR-2964a-5p binds more tightly to " $\mathrm{T}$ " allele of rs4585 and represses ATM expression more strongly compared to "G" allele. This data was validated by using a luciferase reporter gene method, as well as in vitro assays. Most importantly, our data have suggested that patients carrying the rs4585 "T" allele in the 3'-UTR of ATM, show a higher risk for ARC development, and exhibit lower ATM expression within the lens tissues of most of ARC subtypes, with an exception of the nuclear cataract subtype.

In the eye lens, oxidative stress may induce various types of DNA damage, which consequently, may cause cataract [38-40]. In our previous study [41], we found that DNA damage in LECs was positively related to that in peripheral lymphocytes. In addition, different DNA damage of peripheral lymphocytes was detected in individuals with different genotypes [42]. This data support a notion that systematic oxidative stress might attribute to the local lesion of the lens. In this study, we found that the extent of DNA breaks in peripheral lymphocytes, analyzed using the Comet assay, was significantly higher in all ARC subtypes, regardless of the genotype. These results were in line with the results obtained by Ates et al. which found an elevated levels of 8-OH-Gua, a marker of oxidative DNA 
damage, in the leukocytes of patients with cataract [43]. However, the control lymphocytes, which presumably represent a mixture of genotypes, had dramatically lower breakage than the cataract patients in our study. This data has suggested that there is another factor involved in this mechanism, and that presumably has a larger effect on DNA breakage compared to rs4585 genotype. However, the measurement of more subtle oxidative lesion in lens tissues and the characterization of its correlation with the SNP genotypes are still warranted in our future studies.

Recently, a subset of the long non-coding RNAs (lncRNAs) has been reported to interact with miRNAs by complementary sequence, and to act as a miRNA decoy or sponge, which then indirectly influences the miRNA regulation of other proteincoding genes. It has been also demonstrated that, the

A

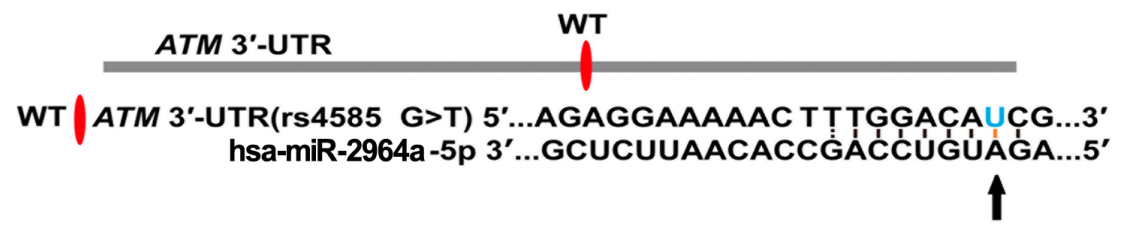

B

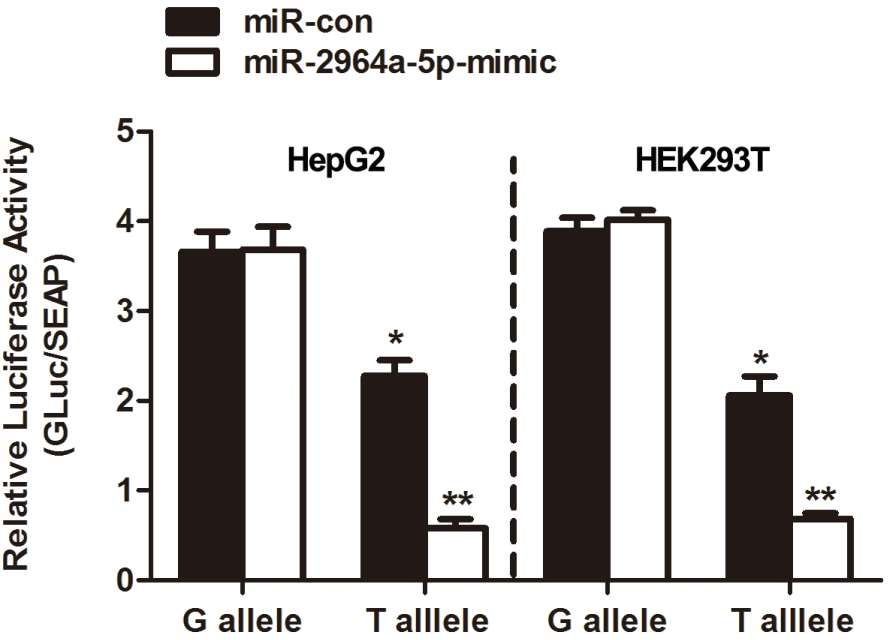

C

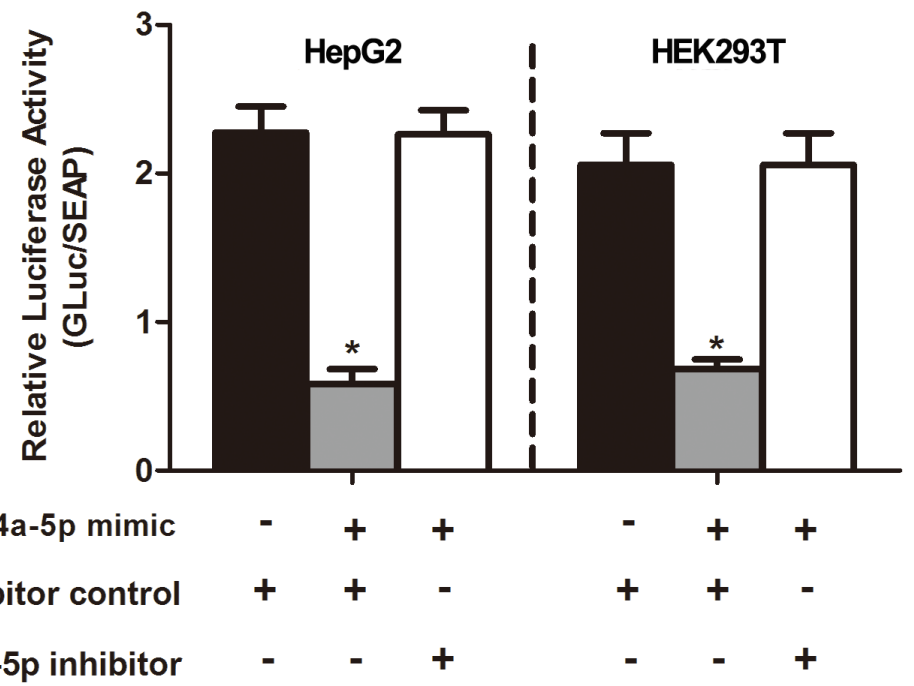

Figure 1: The effect of miR-2964a-5p on miRSNP rs4585. (A) The schema showed predicted binding site of miR-2964a-5p in the 3'-UTR of the ATM. (B) MiR-2964a-5p mimics or miR-con was co-transfected with the reporter constructs containing $\mathrm{G}$ allele or T allele into HEK293T or HepG2 cells. ": $P<0$. 05, compared with G allele group; ${ }^{* *}: P<0.01$, compared with miR-con group. (C) MiR-2964a-5p mimics, inhibitors or miR inhibitor control was co-transfected with the reporter gene containing T allele into HepG2 or HEK293T cells. *: $P<0$. 01, compared with miR inhibitor control group. 
presence of SNPs in miRNA target sites of lncRNAs, may impact the expression of lncRNA by influencing the miRNA-lncRNA interactions, therefore promoting or inhibiting the occurrence and development of diseases. For example, Jing et al. have found a functional polymorphism in lnc-LAMC2-1:1which conferred risk of colorectal cancer by affecting miRNA binding [44]. Tao et al. have demonstrated that the function of the SNP rs145204276 might be mediated by affecting methylation status of the GAS5 promoter and subsequently its transcriptional activity thus serving as a potential therapy target for hepatocellular carcinoma [45]. Moreover, Ling et al. have identified a colon cancer susceptibility SNP rs6983267 which may exert its function by regulating the expression of lncRNA CCAT2 [46]. Therefore, we hypothesized that there may exist functional SNPs within lncRNAs, especially in miRNA:lncRNA binding sites, which are associated with the occurrence of ARC. Further studies are necessary to investigate these loci.

To conclude, our results have suggested that miRSNP rs4585 "T" allele of ATM gene may be associated with increased risk for ARC in Han Chinese population. The mechanism underlying may be that the " $\mathrm{T}$ " variant
A

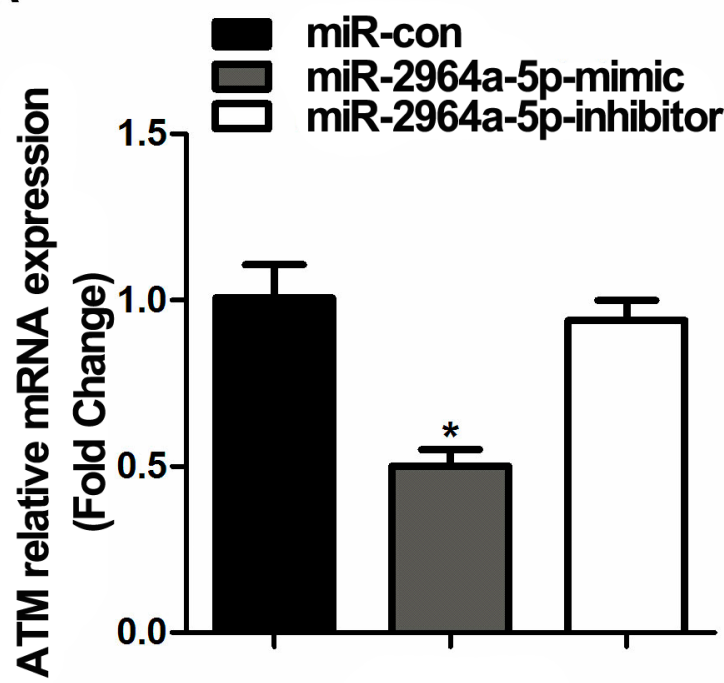

HEK-293T

C

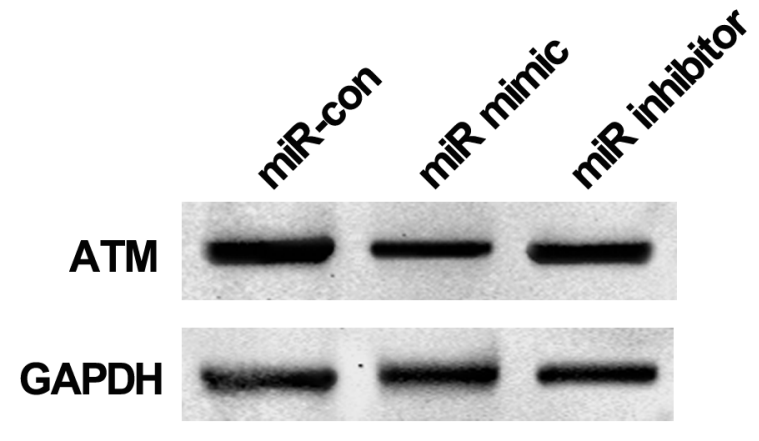

HLEPIC
B

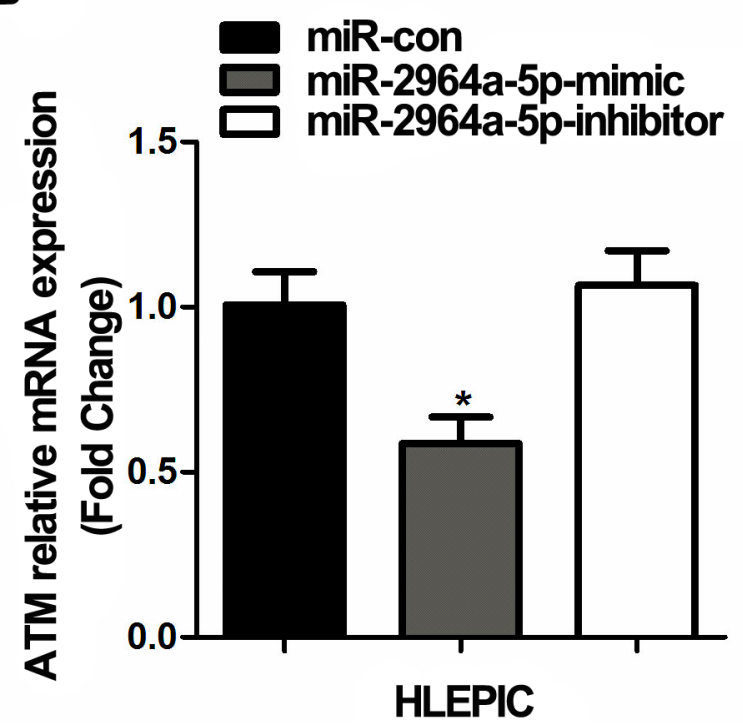

D

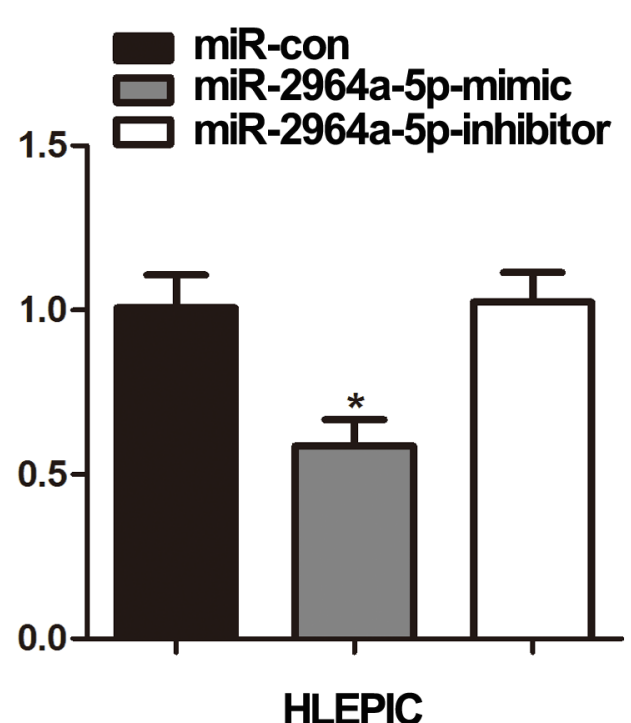

Figure 2: The correlation of SNP rs4585 with $\boldsymbol{A T M}$ expression in vitro. (A) Analysis of $A T M$ mRNA expression in HEK293T cells (TT) transfected with miR-2964a-5p mimics and inhibitors. (B) Analysis of ATM mRNA levels in HLEPIC-LECs (TT) transfected with the miR-2964a-5p mimics and inhibitors. (C) Western blot analysis and quantification (D) of ATM expression in HLEPIC-LECs (TT) transfected with the miR-2964a-5p mimics and inhibitors. " $: P<0.01$, compared with control group. 
of rs4585 enhanced miR-2964a-5p regulatory affinity to the 3'-UTR of the ATM gene, which in turn may disrupt the post-transcriptional regulation of the ATM gene, thus contributing to ARC.

\section{METHODS}

The research acted in adherence to the tenets of the Declaration of Helsinki. All participants signed
A

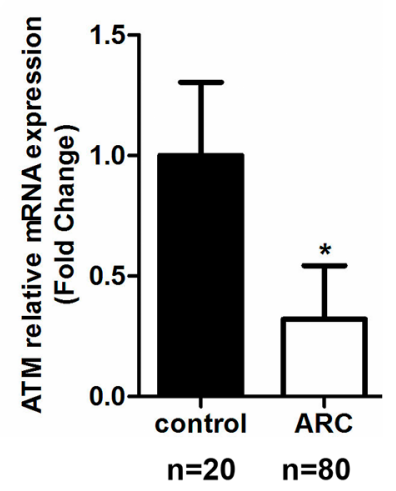

D

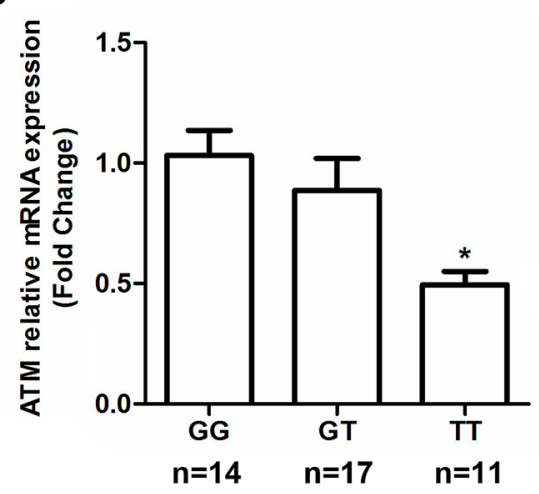

C

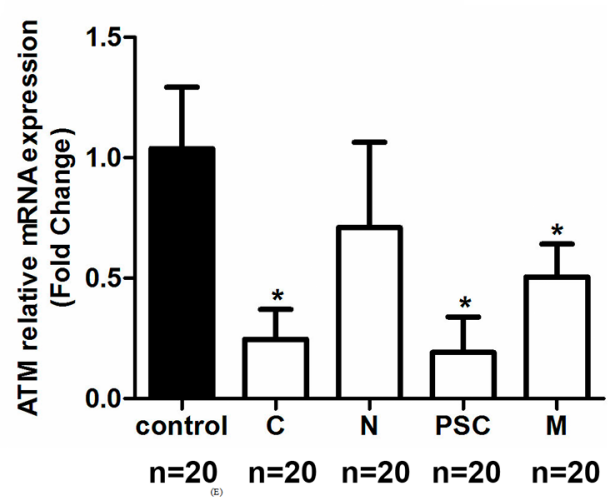

E

$\mathbf{F}$

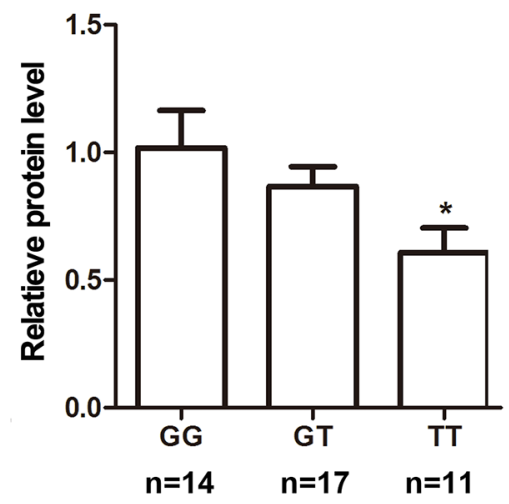

Figure 3: The correlation of SNP rs4585 with $\boldsymbol{A T M}$ expression in anterior capsules. (A) ATM mRNA expression was lower in ARC group than the non-ARC group regardless of genotypes. (B) After stratifying ARC by the subtypes, ATM mRNA levels were markedly decreased in the cortical, posterior subcapsular and mixed types of ARC regardless of genotypes. (C) Levels of miR-2964a-5p in anterior capsules of three genotypes were similar in ARC, $P=0.2190$. (D) ATM mRNA levels in ARC were lower in TT group than the GG or GT group. (E) Western blot analysis and quantification (F) of $A T M$ expression in samples from GG, GT or TT group of ARC. * $P<0.01$.

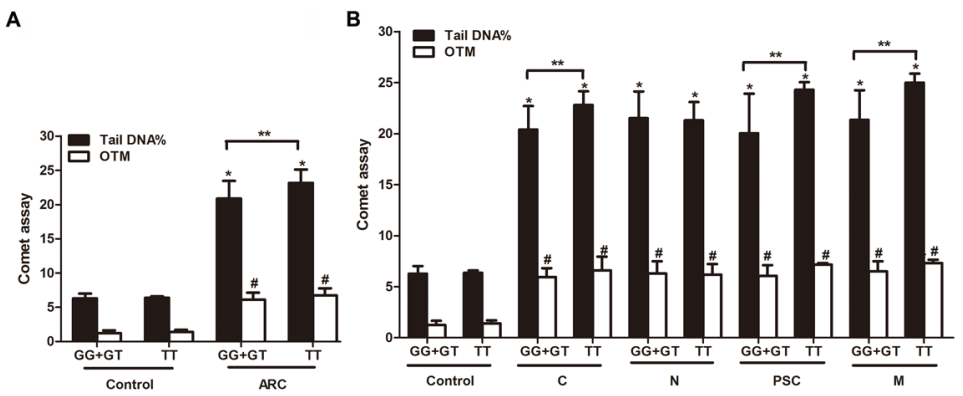

Figure 4: The correlation of rs4585-T with DNA breaks and ARC risk. (A) ARC had more DNA breaks than the control and TT carriers had more DNA damage than GG+GT carriers in ARC. (B) TT carriers had more DNA damage than GG+GT carriers in cortical, posterior subcapsular and mixed cataract patients, in addition to nuclear cataracts. ${ }^{*}: P<0.01$, compared with control group of GG+GT genotype $(\mathrm{n}=27),{ }^{*}: P<0.01$, compared with control group of TT genotype $(\mathrm{n}=5),{ }^{* *}: P<0.05$, compared with corresponding ARC patients with $\mathrm{GG}+\mathrm{GT}$ carriers. 
the respective informed consent forms. The study was approved by the Ethics Committee of Affiliated Hospital of Nantong University.

This study was a part of population-based epidemiologic survey of the Jiangsu Eye Study [3, 16, 42, 47]. The sampling method and inclusion/exclusion criteria for this on-going cohort were in consistent with our previous study [3]. Briefly, the cataract was defined as opacification of ocular lens and best-corrected visual acuity (BCVA) $>20 / 40$. Lens opacities were graded according to the Lens Opacities Classification System III (LOCSIII) [48] in 0.1 unit steps for each opacity up to a maximum of 6.9 for nuclear opacities, and 5.9 for cortical and posterior subcapsular. The presence of more than one cataract type in at least one eye, or different pure types in both eyes were classified into the mixed type [49]. Patients with cataracts due to trauma, diabetes mellitus, uveitis, glaucoma and other causes were excluded from the study. As a result, there were 834 ARC patients included in this study. There were 30 cases failed in DNA extraction and genotyping. We finally examined 804 ARC patients. The non-ARC controls were also selected from the epidemiologic study population without cataracts. After matching for age and sex, 804 individuals were included as normal controls.

In order to measure mRNA, protein and miRNA levels in lens tissues of ARC patients and normal controls, additional $80 \mathrm{ARC}$ patients (cortical $=20$, nuclear $=20$, posterior subcapsular $=20$ and mixed=20) from our clinic (Affiliated Hospital of Nantong University) were included for lens epithelial cells (LECs) collection during the surgery. The control transparent lens was obtained from 20 age-matched subjects who had lens extraction during epiretinal membrane removal. All those clinical cases received phacoemulsification and intraocular lens implantation. There were no statistically significant differences between the two groups regarding the age $(P>0.05)$.

\section{Selection of miRSNPs and SNP genotyping}

We used database and literature search to screen DSBR genes and focused on ATM pathway for this project. A 3'-UTR dataset and a miRNA target dataset of human genes were obtained from the databases of NCBI dbSNP BUILED129 (http://www.ncbi.nlm.nih.gov/SNP) and the International HapMap Project (http://hapmap.ncbi.nlm.nih. gov/). The online softwares miRNASNPV2.0 (http://www. bioguo.org/miRNASNP2/geneTargets.php) and TargetScan V5.1 (http://targetscan.org/) were used to predict the possible miRNA binding-sites in the 3'-UTR. We excluded SNPs with minor allele frequencies (MAF) less than $10 \%$ in the HapMap CHB population. A further selection criterion was a SNP with $\mathrm{r}^{2}$ value $\leq 0.8$ in comparing with its neighboring loci to exclude strong linkage disequilibrium between adjacent variants. The selected SNPs in 7 DSBR genes are listed in Table 2.
Peripheral venous blood was collected in an EDTA anticoagulation tube. Genomic DNA was isolated from leukocytes by the phenol-chloroform method. Genotyping of all SNPs were conducted with a commercial gene expression assay (TaqMan Assay; Applied Biosystems, Foster City, CA, USA), as described in our previous publications $[50,51]$.

\section{LECs collection and DNA/RNA/protein isolation}

The LECs were collected by anterior continuous curvilinear capsulorhexis during cataract surgery. The LECs were collected from transparent anterior capsulorhexis of controls and opaque anterior capsulorhexis of ARC patients. The sample was rapidly frozen in liquid nitrogen, and then stored at $-80^{\circ} \mathrm{C}$ for later extraction of genomic DNA, RNA and protein.

\section{Cell culture and co-transfection}

Human lens epithelial cell line (HLEPIC) and human embryonic kidney cell line (HEK-293T) and human hepatoblastoma cell line (HepG2) were purchased from American Type Culture Collection (ATCC; Rockville, MD, USA). Cells were cultured in Dulbecco's modified Eagle's medium (DMEM; Invitrogen, CA, USA) supplemented with $10 \%$ fetal bovine serum (FBS; Invitrogen, CA, USA) at $37{ }^{\circ} \mathrm{C}$ in a humidified incubator with $5 \% \mathrm{CO}_{2}$. Low passage cells were used in experiments 24 hours before transfection, cells were plated onto a 24well plate at a density of $2 \times 10^{5}$ cells/well. The transfection was conducted when cells reached $80 \%$ confluence.

HEK-293T and HepG2 cells were transiently cotransfected with reporter plasmids and miRNA mimics or inhibitors (Ribobio, Guangzhou, China). HEK-293T and HLEPIC cells were only transfected with miRNA mimics or inhibitors for qRT-PCR or Western blot assays. The miRNA inhibitors were chemically-modified and optimized complementary single stranded nucleic acids designed to specifically target the miRNA and knockdown individual miRNA molecules.

\section{Plasmids construct}

The luciferase assay was used as the reporter system to assess functional consequences for the significant 3'UTR SNP rs4585. We first synthesized oligonucleotides that contain $201 \mathrm{bp}$ surrounding SNP rs4585 in three tandem copies and used the restriction enzymes EcoRI and XhoI for cloning sites. The cloning sites exploited for generation of reporter construct (rs4585) were as follows: tggtcattatagtatatgcctaaaatgtatgcacttaggaatgctaaaaatttaaatat ggtctaaagcaaataaaagcaaagaggaaaaactttggacaG/Tcgtaaagact agaatagtcttttaaaaagaaagccagtatattggtttgaaatatagagatgtgtccc aatttcaagtattttaattgcaccttaatgaa. The oligonucleotides were cloned into the secreted Gaussia luciferase (GLuc) reporter gene system, driven by SV40 promoter for expression 
in mammalian cells. A secreted Alkaline Phosphatase (SEAP) reporter, driven by a CMV promoter, was also cloned into the same vector (pEZX-MT05; GeneCopoeia, Rockville, USA) and served as the internal control. The minor T allele of rs4585 was similarly constructed. All constructs were confirmed by DNA sequencing.

\section{Luciferase reporter assay}

For luciferase reporter assays, HEK-293T cells and HepG2 cells were co-transfected with $600 \mathrm{ng}$ of ATM 3'-UTR luciferase plasmid (pEZX-MT05) and miRNA mimics/inhibitors or control miRNA mimic, using Lipofectamine 2000 (Invitrogen, CA, USA). Gaussian luciferase and alkaline phosphatase activities were measured by luminescence in conditioned medium 48 hours after transfection using these secreted-pair dual luminescence kit (GeneCopoeia, Rockville, USA). Gaussian luciferase activity was normalized to alkaline phosphatase activity. Each sample was measured in triplicate using the Glomax Luminometer (BioTek, Beaumont, Texas, USA).

\section{RNA isolation and cDNA preparation}

Total RNA was isolated from the frozen LEC tissues or cell culture using TRIzol reagent (Invitrogen, CA, USA) and cDNAs were synthesized using Prime Script ${ }^{\circledR}$ RT reagent Kit (Takara, Dalian, China).

\section{Quantification of mRNA and miRNA expression}

TaqMan gene expression assay probes (Applied Biosystems, USA) were used for ATM mRNA quantification (assay ID: Hs01112355_g1). Human beta-actin (assay ID: Hs01060665_m1) was chosen as housekeeping gene for normalization. Measurement of miRNA levels in lens anterior capsules samples were determined by qRT-PCR with primers (GeneCopoiea, Rockville, USA) specific for candidate miRNA. qRT-PCR was carried out using the All-in-OneTM miRNA qRT-PCR Detection Kit (GeneCopoiea, USA). U6 small nuclear RNA (snRNA) was selected as the endogenous control. The catalog numbers of All-in-One miRNA qPCR Primers were as follows: hsa-miR-2964a-5p HmiRQP1876; snRNA U6 HmiRQP9001.qRT-PCR was performed using ABI 7500 real time PCR system (Applied Biosystems, USA). The fold change of gene or miRNA expression was determined using the comparative CT $\left(2^{-\Delta \Delta \mathrm{CT}}\right)$ method.

\section{Western blot assay}

The protein of LECs and HLEPIC were extracted separately in lysis buffer ( $1 \mathrm{M}$ Tris- $\mathrm{HCl}$ at $\mathrm{pH} 7.5,1 \%$ Triton X-100,1\% Nonidet p-40, 10\% SDS, 0.5\% sodium deoxycholate, 0.5 M EDTA, $10 \mu \mathrm{g} / \mathrm{ml}$ leupeptin, 10 $\mu \mathrm{g} / \mathrm{ml}$ aprotinin, and $1 \mathrm{mM}$ phenylmethylsulfonyl fluoride [PMSF]). Equal amounts of proteins were size fractionated by sodium dodecyl sulfate-polyacrylamide gel electrophoresis on $15 \%$ polyacrylamide gels. Proteins were then transferred onto polyvinylidene difluoride filter membranes (Millipore, Bedford, MA, USA). The blocked membrane was then incubated with mouse antihuman-ATM (Sigma) and mouse antihuman-GAPDH (1:1000; Abcam, Cambridge, UK) at $4{ }^{\circ} \mathrm{C}$ for 12 hours. After washing, the membrane was incubated with an alkaline phosphatase-conjugated goat anti-mouse IgG antibody (1:2000; Santa Cruz) for 2 hours. An enhanced chemiluminescence detection system was used to read the Western signals (Pierce Company, USA).

\section{Comet assay}

The Comet assay (also known as the Single Cell Gel Electrophoresis assay) is a sensitive technique for the detection of DNA damage at the level of an individual cell. We collected fresh blood from 106 ARC patients ( cortical $=44$, nuclear $=30$, posterior subcapsular $=10$ and mixed $=22$ ) and 32 age and sex matched normal controls in the Jiangsu Eye Study for Comet assay that measures DNA breaks of lymphocytes and the genotyping. The modified Comet assay for lymphocytes and data analysis was carried out according to the method described by Zhang et al [41]. OTM, defined as the product of the distance between the barycenters of the head and tail by the percentage of DNA in the tail of the Comet-like images, was used to evaluate the extent of DNA damage (DNA breaks) in individual cells.

\section{Statistical analysis}

Statistical analyses were performed with a commercial statistical software program (Stata 8.0; Stata Corp, College Station, TX). The $\mathrm{X}^{2}$ test was used to test the association between the alleles frequencies of all ARC patients and healthy controls and various ARC subtypes. In addition, $\mathrm{X}^{2}$ test was used to analyzelestimate odds ratios (OR) and 95\% confidence interval (CI), as well as Hardy-Weinberg Equilibrium (HWE) of genotype distributions. If positive association was found in the initial allele analysis, Bonferroni correction was performed. Various genetic model analyses were performed to characterize the association as dominant (heterozygote and homozygote versus wild type), recessive model (homozygote versus wild type and heterozygote), additive model (homozygote versus heterozygote versus wild type), and heterozygote advantage model (heterozygote versus homozygote and wild type). We only present the most significant model in the results. In addition, all in vitro experiments were done independently and in triplicated. Statistical comparisons of the average values of 2 groups were performed using the Student $t$ test, or assessed by one-way analysis of variance (ANOVA) when more than two groups were analyzed, with a $P$ value of $>0.05$ considered significant. 


\section{Note}

The web-based software "miRNA SNP" (http:// www.bioguo.org/miRNASNP2/geneTargets.php) that was used in the study design has been removed by the owner and is no longer available. The minimal free energy (MFE) analysis by paring the sequences of hsa-miR-2964a5p (hsa-miR-219b-5p, identical miRNA with different annotation) and rs4585, the major discovery of this work, indicates $-18.9 \mathrm{kcal} / \mathrm{mol}$ in MFE (https://bibiserv. cebitec.uni-bielefeld.de/sessionTimeout.jsf). The common agreement in the field is that $-20 \mathrm{kcal} / \mathrm{mol}$ in MFE is the cut-off for a suitable binding potential, therefore -18.9 $\mathrm{kcal} / \mathrm{mol}$ in our case indicates a suitable binding potential between the hsa-miR-2964a-5p and DNA sequence around rs4585. (see below).

\begin{tabular}{|c|c|c|c|c|c|c|}
\hline $\begin{array}{l}\text { SNP in } \\
\text { gene } 3^{\prime} U T R\end{array}$ & miRNA & SNP location & $\begin{array}{l}\text { Energy } \\
\text { change } \\
\text { (kcal/mol) }\end{array}$ & & miRNA/SNP-target duplexes & $\begin{array}{l}\text { Effec } \\
\text { by } \\
\text { SNP } \\
\text { on } \\
3^{\prime} \text { UT }\end{array}$ \\
\hline $\begin{array}{l}\text { ATM(NM_000051): } \\
\text { s4585 } \\
\text { G/U) }\end{array}$ & $\begin{array}{l}\text { hsa-miR. } \\
\text { 2964a-5p }\end{array}$ & chr11:108239628 & $\begin{array}{l}\text { Wild Type: } \\
0.00 \\
\text { SNP Type: } \\
=23.20\end{array}$ & $\begin{array}{l}\text { MiRNA: } \\
\text { UTR: }\end{array}$ & 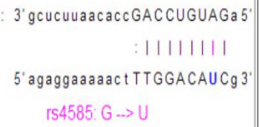 & gai \\
\hline
\end{tabular}

\section{Author contributions}

H.R. designed the experiments. H.R. and S.S.G performed the experiments. H.R. and M.Y. performed the data analysis. H.R. wrote the paper. J.F.Z., X.Y.S. and L.H.K. contributed the clinical samples. G.W.Z and H.J.G. revised the paper. All authors contributed to scientific discussions.

\section{ACKNOWLEDGMENTS}

Support was provided by the National Natural Science Foundation of China (No. 81470616, 81300744 and 81500706), Science Foundation of Nantong China Grant (HS2014005) and Graduate student innovation fund (YKS14014).

\section{CONFLICTS OF INTEREST}

The authors declare that they have no conflicts of interest.

\section{REFERENCES}

1. Klein BE, Klein R, Linton KL. Prevalence of age-related lens opacities in a population. The Beaver Dam Eye Study. Ophthalmology. 1992; 99:546-52.

2. Asbell PA, Dualan I, Mindel J, Brocks D, Ahmad M, Epstein S. Age-related cataract. Lancet. 2005; 365:599-609.
3. Su S, Yao Y, Zhu R, Liang C, Jiang S, Hu N, Zhou J, Yang M, Xing Q, Guan H. The associations between single nucleotide polymorphisms of DNA repair genes, DNA damage, and age-related cataract: Jiangsu Eye Study. Invest Ophthalmol Vis Sci. 2013; 54:1201-07.

4. Liu XC, Liu XF, Hu ZD, Li ZH. Polymorphisms of DNA repair genes XPD (Lys751Gln) and XRCC1 (Arg399Gln), and the risk of age-related cataract: a meta-analysis. Curr Eye Res. 2015; 40:676-82.

5. Lees-Miller SP, Meek K. Repair of DNA double strand breaks by non-homologous end joining. Biochimie. 2003; 85:1161-73.

6. Orii KE, Lee Y, Kondo N, McKinnon PJ. Selective utilization of nonhomologous end-joining and homologous recombination DNA repair pathways during nervous system development. Proc Natl Acad Sci USA. 2006; 103:10017-22.

7. Mills KD, Ferguson DO, Essers J, Eckersdorff M, Kanaar R, Alt FW. Rad54 and DNA Ligase IV cooperate to maintain mammalian chromatid stability. Genes Dev. 2004; 18:1283-92.

8. Beucher A, Birraux J, Tchouandong L, Barton O, Shibata A, Conrad S, Goodarzi AA, Krempler A, Jeggo PA, Löbrich M. ATM and Artemis promote homologous recombination of radiation-induced DNA double-strand breaks in G2. EMBO J. 2009; 28:3413-27.

9. Wang W, Jiang J, Zhu Y, Li J, Jin C, Shentu X, Yao K. A novel mutation in the major intrinsic protein (MIP) associated with autosomal dominant congenital cataracts in a Chinese family. Mol Vis. 2010; 16:534-39.

10. Khanna KK, Jackson SP. DNA double-strand breaks: signaling, repair and the cancer connection. Nat Genet. 2001; 27:247-54.

11. Chen T, Dong B, Lu Z, Tian B, Zhang J, Zhou J, Wu H, Zhang Y, Wu J, Lin P, Zhang J, Xu H, Mo X. A functional single nucleotide polymorphism in promoter of ATM is associated with longevity. Mech Ageing Dev. 2010; 131:636-40.

12. Rondeau S, Vacher S, De Koning L, Briaux A, Schnitzler A, Chemlali W, Callens C, Lidereau R, Bièche I. ATM has a major role in the double-strand break repair pathway dysregulation in sporadic breast carcinomas and is an independent prognostic marker at both $\mathrm{mRNA}$ and protein levels. Br J Cancer. 2015; 112:1059-66.

13. Cui NH, Qiao C, Chang XK, Wei L. Associations of PARP-1 variant rs1136410 with PARP activities, oxidative DNA damage, and the risk of age-related cataract in a Chinese Han population: A two-stage case-control analysis. Gene. 2017; 600:70-76.

14. Gu S, Rong H, Zhang G, Kang L, Yang M, Guan H. Functional SNP in 3'-UTR MicroRNA-Binding Site of ZNF350 Confers Risk for Age-Related Cataract. Hum Mutat. 2016; 37:1223-30. 
15. Zheng LR, Ma JJ, Zhou DX, An LF, Zhang YQ. Association between DNA repair genes (XPD and XRCC1) polymorphisms and susceptibility to age-related cataract (ARC): a meta-analysis. Graefes Arch Clin Exp Ophthalmol. 2014; 252:1259-66.

16. Jiang S, Hu N, Zhou J, Zhang J, Gao R, Hu J, Guan H. Polymorphisms of the WRN gene and DNA damage of peripheral lymphocytes in age-related cataract in a Han Chinese population. Age (Dordr). 2013; 35:2435-44.

17. Bu J, He S, Wang L, Li J, Liu J, Zhang X. A novel splice donor site mutation in EPHA2 caused congenital cataract in a Chinese family. Indian J Ophthalmol. 2016; 64:364-68.

18. Cano A, Pérez-Moreno MA, Rodrigo I, Locascio A, Blanco MJ, del Barrio MG, Portillo F, Nieto MA. The transcription factor snail controls epithelial-mesenchymal transitions by repressing E-cadherin expression. Nat Cell Biol. 2000; 2:76-83.

19. Calin GA, Croce CM. MicroRNA signatures in human cancers. Nat Rev Cancer. 2006; 6:857-66.

20. Bartel DP. MicroRNAs: target recognition and regulatory functions. Cell. 2009; 136:215-33.

21. Liang L, Zhu J, Zaorsky NG, Deng Y, Wu X, Liu Y, Liu F, Cai G, Gu W, Shen L, Zhang Z. MicroRNA-223 enhances radiation sensitivity of $\mathrm{U} 87 \mathrm{MG}$ cells in vitro and in vivo by targeting ataxia telangiectasia mutated. Int J Radiat Oncol Biol Phys. 2014; 88:955-60.

22. Sethupathy P, Borel C, Gagnebin M, Grant GR, Deutsch $\mathrm{S}$, Elton TS, Hatzigeorgiou AG, Antonarakis SE. Human microRNA-155 on chromosome 21 differentially interacts with its polymorphic target in the AGTR1 3' untranslated region: a mechanism for functional single-nucleotide polymorphisms related to phenotypes. Am J Hum Genet. 2007; 81:405-13.

23. Chin LJ, Ratner E, Leng S, Zhai R, Nallur S, Babar I, Muller RU, Straka E, Su L, Burki EA, Crowell RE, Patel R, Kulkarni T, et al. A SNP in a let-7 microRNA complementary site in the KRAS $3^{\prime}$ untranslated region increases non-small cell lung cancer risk. Cancer Res. 2008; 68:8535-40.

24. Abelson JF, Kwan KY, O’Roak BJ, Baek DY, Stillman AA, Morgan TM, Mathews CA, Pauls DL, Rasin MR, Gunel M, Davis NR, Ercan-Sencicek AG, Guez DH, et al. Sequence variants in SLITRK1 are associated with Tourette's syndrome. Science. 2005; 310:317-20.

25. Tan Z, Randall G, Fan J, Camoretti-Mercado B, BrockmanSchneider R, Pan L, Solway J, Gern JE, Lemanske RF, Nicolae D, Ober C. Allele-specific targeting of microRNAs to HLA-G and risk of asthma. Am J Hum Genet. 2007; 81:829-34.

26. Wang G, van der Walt JM, Mayhew G, Li YJ, Züchner S, Scott WK, Martin ER, Vance JM. Variation in the miRNA433 binding site of FGF20 confers risk for Parkinson disease by overexpression of alpha-synuclein. Am J Hum Genet. 2008; 82:283-89.
27. Renaud E, Rosselli F. FANC pathway promotes UV-induced stalled replication forks recovery by acting both upstream and downstream Pol $\eta$ and Rev1. PLoS One. 2013; 8:e53693.

28. Fanale D, Amodeo V, Corsini LR, Rizzo S, Bazan V, Russo A. Breast cancer genome-wide association studies: there is strength in numbers. Oncogene. 2012; 31:2121-28.

29. Lalloo F, Evans DG. Familial breast cancer. Clin Genet. 2012; 82:105-14.

30. Yang G, Zhang G, Pittelkow MR, Ramoni M, Tsao H. Expression profiling of UVB response in melanocytes identifies a set of p53-target genes. J Invest Dermatol. 2006; 126:2490-506.

31. Sarker AH, Chatterjee A, Williams M, Lin S, Havel C, Jacob P 3rd, Boldogh I, Hazra TK, Talbot P, Hang B. NEIL2 protects against oxidative DNA damage induced by sidestream smoke in human cells. PLoS One. 2014; 9:e90261.

32. Li F, Wang Y, Zhang G, Zhou J, Yang L, Guan H. Expression and methylation of DNA repair genes in lens epithelium cells of age-related cataract. Mutat Res. 2014; 766-767:31-36.

33. Ding X, Yue JR, Yang M, Hao QK, Xiao HY, Chen T, Gao LY, Dong BR. Association between the rs189037 single nucleotide polymorphism in the ATM gene promoter and cognitive impairment. Genet Mol Res. 2015; 14:4584-92.

34. Lin F, Li R, Pan ZX, Zhou B, Yu DB, Wang XG, Ma XS, Han J, Shen M, Liu HL. miR-26b promotes granulosa cell apoptosis by targeting ATM during follicular atresia in porcine ovary. PLoS One. 2012; 7:e38640.

35. Mansour WY, Bogdanova NV, Kasten-Pisula U, Rieckmann T, Köcher S, Borgmann K, Baumann M, Krause M, Petersen C, Hu H, Gatti RA, Dikomey E, Dörk T, Dahm-Daphi J. Aberrant overexpression of miR-421 downregulates ATM and leads to a pronounced DSB repair defect and clinical hypersensitivity in SKX squamous cell carcinoma. Radiother Oncol. 2013; 106:147-54.

36. Jiang Y, Chen J, Wu J, Hu Z, Qin Z, Liu X, Guan X, Wang Y, Han J, Jiang T, Jin G, Zhang M, Ma H, et al. Evaluation of genetic variants in microRNA biosynthesis genes and risk of breast cancer in Chinese women. Int J Cancer. 2013; 133:2216-24.

37. Wu C, Lin H, Wang Q, Chen W, Luo H, Chen W, Zhang H. Discrepant expression of microRNAs in transparent and cataractous human lenses. Invest Ophthalmol Vis Sci. 2012; 53:3906-12.

38. Ehrenberg M, Dratviman-Storobinsky O, Avraham-Lubin BR, Goldenberg-Cohen N. Lack of association of the WRN C1367T polymorphism with senile cataract in the Israeli population. Mol Vis. 2010; 16:1771-75.

39. Kleiman NJ, Wang RR, Spector A. Hydrogen peroxideinduced DNA damage in bovine lens epithelial cells. Mutat Res. 1990; 240:35-45. 
40. Li WC, Kuszak JR, Dunn K, Wang RR, Ma W, Wang GM, Spector A, Leib M, Cotliar AM, Weiss M, et al. Lens epithelial cell apoptosis appears to be a common cellular basis for non-congenital cataract development in humans and animals. J Cell Biol. 1995; 130:169-81.

41. Zhang J, Wu J, Yang L, Zhu R, Yang M, Qin B, Shi H, Guan H. DNA damage in lens epithelial cells and peripheral lymphocytes from age-related cataract patients. Ophthalmic Res. 2014; 51:124-28.

42. Jiang J, Zhou J, Yao Y, Zhu R, Liang C, Jiang S, Yang M, Lu Y, Xing Q, Guan H. Copy number variations of DNA repair genes and the age-related cataract: Jiangsu Eye Study. Invest Ophthalmol Vis Sci. 2013; 54:932-38.

43. Ates O, Alp HH, Kocer I, Baykal O, Salman IA. Oxidative DNA damage in patients with cataract. Acta Ophthalmol. 2010; 88:891-95.

44. Gong J, Tian J, Lou J, Ke J, Li L, Li J, Yang Y, Gong Y, Zhu Y, Zhang Y, Zhong R, Chang J, Miao X. A functional polymorphism in lnc-LAMC2-1:1 confers risk of colorectal cancer by affecting miRNA binding. Carcinogenesis. 2016; $37: 443-51$.

45. Tao R, Hu S, Wang S, Zhou X, Zhang Q, Wang C, Zhao X, Zhou W, Zhang S, Li C, Zhao H, He Y, Zhu S, et al. Association between indel polymorphism in the promoter region of lncRNA GAS5 and the risk of hepatocellular carcinoma. Carcinogenesis. 2015; 36:1136-43.
46. Ling H, Spizzo R, Atlasi Y, Nicoloso M, Shimizu M, Redis RS, Nishida N, Gafà R, Song J, Guo Z, Ivan C, Barbarotto E, De Vries I, et al. CCAT2, a novel noncoding RNA mapping to $8 \mathrm{q} 24$, underlies metastatic progression and chromosomal instability in colon cancer. Genome Res. 2013; 23:1446-61.

47. Zhou J, Hu J, Guan H. The association between copy number variations in glutathione S-transferase M1 and T1 and age-related cataract in a Han Chinese population. Invest Ophthalmol Vis Sci. 2010; 51:3924-28.

48. Chylack LT Jr, Wolfe JK, Singer DM, Leske MC, Bullimore MA, Bailey IL, Friend J, McCarthy D, Wu SY, and The Longitudinal Study of Cataract Study Group. The Lens Opacities Classification System III. Arch Ophthalmol. 1993; 111:831-36.

49. Magno BV, Datiles MB 3rd, Lasa SM. Senile cataract progression studies using the Lens Opacities Classification System II. Invest Ophthalmol Vis Sci. 1993; 34:2138-41.

50. Yang X, Hu J, Zhang J, Guan H. Polymorphisms in CFH, HTRA1 and CX3CR1 confer risk to exudative age-related macular degeneration in Han Chinese. Br J Ophthalmol. 2010; 94:1211-14.

51. Hu J, Yuan Y, Shen L, Zhang J, Hu N, Guan H. Age-related macular degeneration-susceptibility single nucleotide polymorphisms in a han chinese control population. Ophthalmic Epidemiol. 2011; 18:137-42. 